\title{
A new species of Schizomyia (Diptera, Cecidomyiidae, Asphondyliini) associated with Tetrapterys phlomoides (Malpighiaceae)
}

\author{
Leticia Iendrike de Sousa \& Valéria Cid Maia
}

Departamento de Entomologia, Museu Nacional, Quinta da Boa Vista, São Cristóvão, 20940-040 Rio de Janeiro, Brazil. (leticiaiendrike@ig.com.br; maiavcid@acd.ufrj.br)

\begin{abstract}
Schizomyia maricaensis sp. nov. is described and illustrated based on the pupa, male, female, and gall. This species induces rosette galls on Tetrapterys phlomoides (Malpighiaceae).
\end{abstract}

KEYWORDS. Gall, morphology, taxonomy, restinga, Brazil.

RESUMO. Uma nova espécie de Schizomyia (Diptera: Cecidomyiidae: Asphondyliini) associada com Tetrapteris phlomoides (Malpighiaceae). Schizomyia maricaensis sp. nov. é descrita e ilustrada com base na pupa, macho, fêmea e galha. Essa espécie induz galhas em forma de roseta em Tetrapterys phlomoides (Malpighiaceae).

PALAVRAS-CHAVE. Galha, morfologia, taxonomia, restinga, Brasil.

Tetrapterys phlomoides (Malpighiaceae) occurs in Brazil. It has been recorded only for the states of Espírito Santo and Rio de Janeiro. MAIA (2001) recorded a rosette bud gall with small cylinders at the bottom on this plant (Maia, 2001: fig. 47). The gall maker was identified at tribe level: Asphondyliini. Morphological studies indicated that this is a new species of Schizomyia Kieffer, 1889 which is described in this paper.

Schizomyia is a catchall genus for Asphondyliini species with needlelike ovipositors, four-segmented palpi, and larvae with all four pairs of terminal papilae present (GAGNÉ, 1994). It includes 48 species, six of them are known in the Neotropical region, where they are associated with Convolvulaceae, Euphorbiaceae, Fabaceae, Sapindaceae and Verbenaceae (GAGNÉ, 2004; MaiA \& FernANDES, 2005).

\section{MATERIAL AND METHODS}

All studied material was obtained from the restinga of Barra de Maricá (Maricá, southest Brazil). Part of it was previously collected and reared by V. C. Maia during the period of 1990 - 1998. Other collections were made at Maricá during 2003 to obtain more material. The rosette galls were taken to the laboratory for rearing of the adults, where samples of galls were maintained in plastic vials covered by a fine screening and layered at the bottom with damp cotton. All vials were checked daily. Pupal exuviae and adults of Cecidomyiidae were preserved in $70 \%$ alcohol and they were later mounted on slides following the methodology of GAGné (1994). The Cecidomyiidae genera were identified based on the key to tribes and genera of Neotropical Cecidomyiidi elaborated by GAGNÉ (1994). All specimens were incorporated in the Diptera collection of Museu Nacional, Rio de Janeiro (MNRJ). The terminology of adult stage and immature stages follows GAGNÉ (1994). The host plant was identified Dr. Andréa Costa (Museu Nacional, Universidade Federal do Rio de Janeiro).

\section{Schizomyia maricaensis sp. nov.}

(Figs. 1-16) locality.

Etymology. The name maricaensis refers to the type

Adult. Body length: $2.89-3.01 \mathrm{~mm}$ in male $(\mathrm{n}=2)$; 2.55-3.28 $\mathrm{mm}$ in female $(\mathrm{n}=5)$.

Head (Fig. 1). Eye facets hexagonal, closely appressed. Antenna with scape rectangular or obconic, pedicel globose, male and female flagellomeres cylindrical, flagellomere necks bare; circunfila anastomosing in both sexes (Figs. 4, 5). Proportions of last four male flagellomeres as in Fig. 2; proportions of last six female flagellomeres as in Fig. 3. Flagellomeres 1 and 2 not connate. Frontoclypeus with about 53 setae. Labrum long-attenuate with three pairs of ventral sensory setae. Hypopharynx of same shape as labrum, with long, anteriorly directed lateral setulae. Labella elongateconvex, each one with several lateral setae and three pairs of short mesal sensory setae. Palpus with four setose crescent segments: segment 1 shortest and obconical, segments 2-4 cylindrical.

Thorax. Anepimeron with 41-57 setae. Other pleural sclerites asetose. Wing (Fig. 6) length (from arculus to apex): 2.11-2.14 $\mathrm{mm}$ in male ( $\mathrm{n}=2) ; 2.27-2.89 \mathrm{~mm}$ in female $(n=5)$. First tarsomeres with short apical spur (Fig. 7). Tarsal claws simple, robust and curved beyond midlength, similar in shape on three pairs of legs; empodia rudimentary (Fig. 8).

Abdomen. Male (Fig. 9): tergites 1-7 rectangular with complete row of posterior setae, some lateral setae, two basal trichoid sensilla and elsewhere with scattered scales. Tergite 8 not sclerotized with only two trichoid sensilla as vestiture. Sternites 2-8 rectangular with setae more abundant at midlength, complete row of posterior setae, two basal trichoid sensilla and elsewhere with scattered scales. Female (Fig. 10): tergites 1-6 as in male. Tergite 7 rectangular with complete row of posterior setae, setae at midlength, two basal trichoid sensilla and 

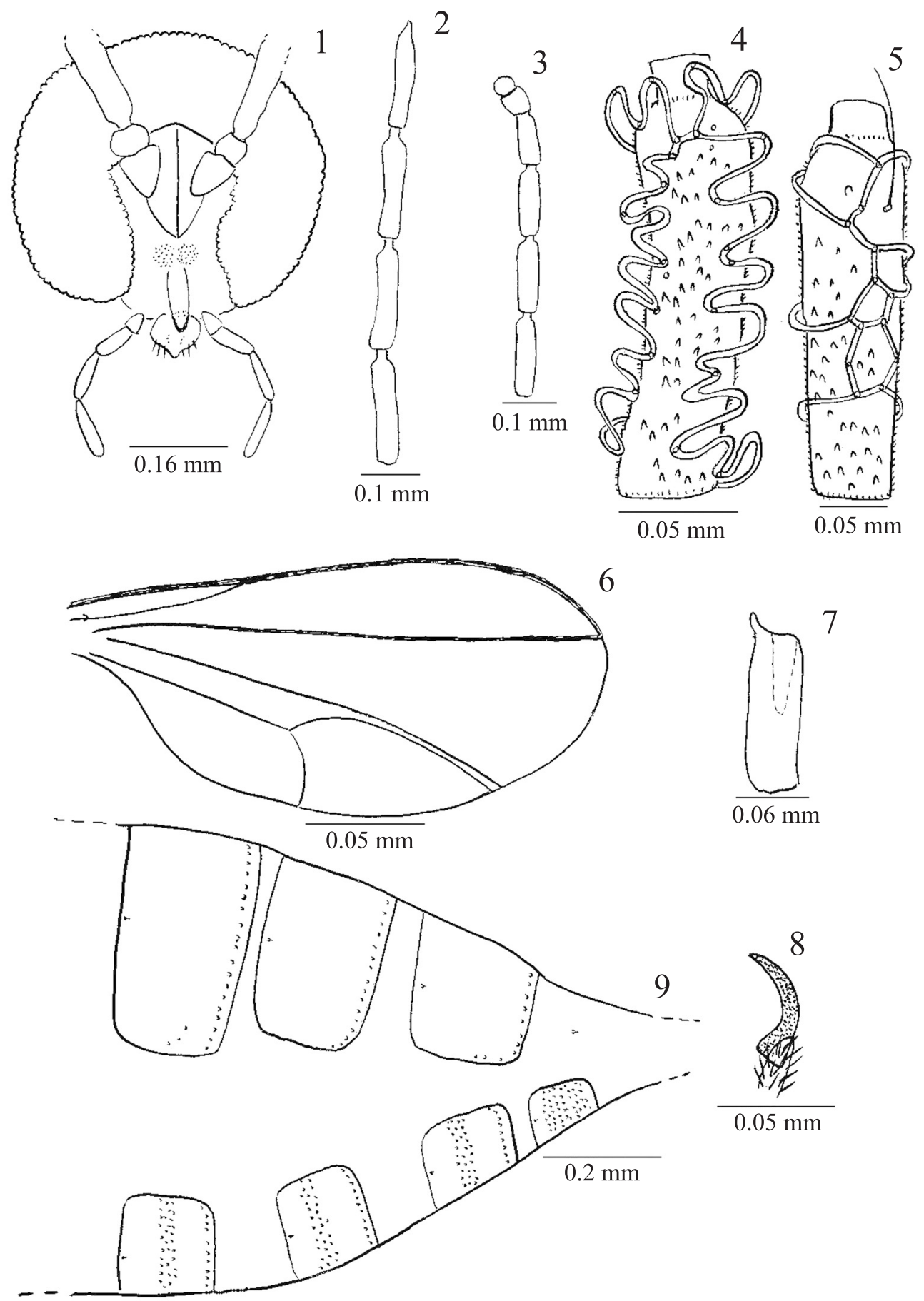

Figs. 1-9. Schizomyia maricaensis sp. nov.: 1, male head, frontal; 2, male antennal flagellomeres 9-12; 3, female antennal flagellomeres 7-12; 4-5, antennal flagellomere 5: 4, male; 5, female; 6, male wing; 7, male, first tarsomere, apical spur; 8 , male, midtarsal claw and empodium, lateral; 9, male abdominal segments 5-8, lateral.

elsewhere with scattered scales. Tergite 8 notched laterally with caudal and mesal setae, two basal tricoid sensilla and elsewhere with scattered scales. Sternites 2-6 as in male. Sternite 7 with scattered setae and two basal trichoid sensilla, twice longer than sternite 6. Sternite 8 not sclerotized.

Male terminalia (Fig. 11): gonocoxites constricted near midlength and setose; gonostylus short, ovoid, and setose; cercus setose, wide, shorter than hypoproct, rounded apically; hypoproct bilobed, narrow and setose; parameres and cercus subequal in length; aedeagus triangular, tapering gradually toward apex, pointed apically.

Ovipositor (Fig. 12) protusible and needlelike, needle part with 1.15-1.4 mm of length.

Pupa. Color brownish. Length 3.0-3.7 mm $(\mathrm{n}=5)$. Head (Fig. 13): antennal horn absent; cephalic setae 0.02$0.04 \mathrm{~mm}$ long $(\mathrm{n}=5)$ (Fig. 14); three pairs of lateral facial 


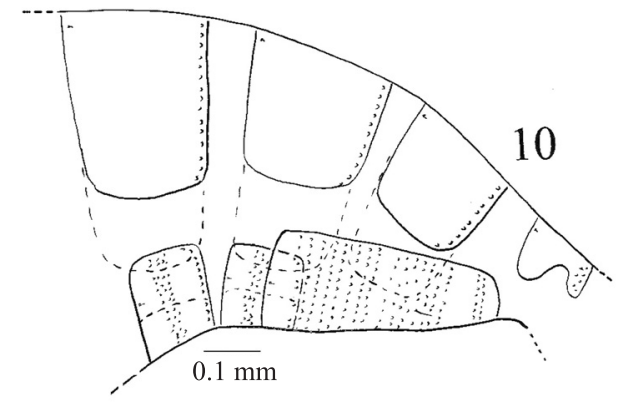

11

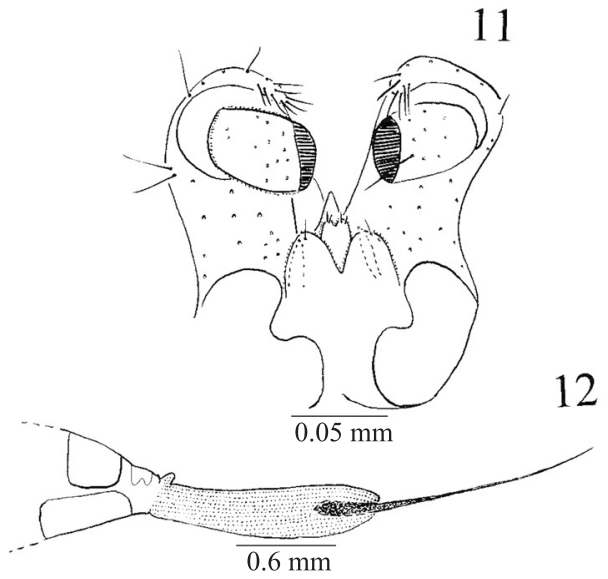

Figs. 10-12. Schizomyia maricaensis sp. nov.: 10, female abdominal segments 4-8, lateral; 11, male terminalia, dorsal; 12, ovipositor, lateral.

papillae (one setose, the others without setae), two pairs of lower facial papillae (one pair asetose, the other with seta). Upper cephalic margin thickened laterally. Thorax: prothoracic spiracle setiform, elongate and curved, 0.12$0.19 \mathrm{~mm}$ long $(\mathrm{n}=5)$ (Fig. 15). Wing sheath reaching basal margin of abdominal segment 4 or midlength of the same segment; foreleg sheath reaching basal margin of abdominal segment 6 or basal third of the same segment; midleg sheath reaching midlength of abdominal segment 6 or distal third of the same segment; hindleg sheath reaching basal margin of abdominal segment 7 or basal third of abdominal segment 7. Abdomen (Fig. 16): segments 3-9 with numerous transverse rows of dorsal spines at discal region and six setose dorsal papillae.

Larvae unknown.

Gall. Rosette bud gall with small cylinders at the bottom; cylinder length: $0.4 \mathrm{~cm}$; cylinder width: $0.1 \mathrm{~cm}$ : glabrous, monothalamous; green.

Material examined. Holotype ơ. Brazil, Rio de Janeiro Maricá, 30.IV.1990, V. Maia leg. (MNRJ). Paratypes: same data as holotype: $\sigma^{\prime}, 2$ ㅇ 9 and 8 pupal exuviae. Same locality and collector: 우

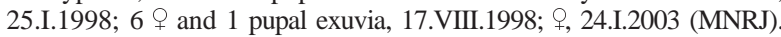

Remarks. Schizomyia maricaensis is easily distinguished from other Schizomyia in having apical
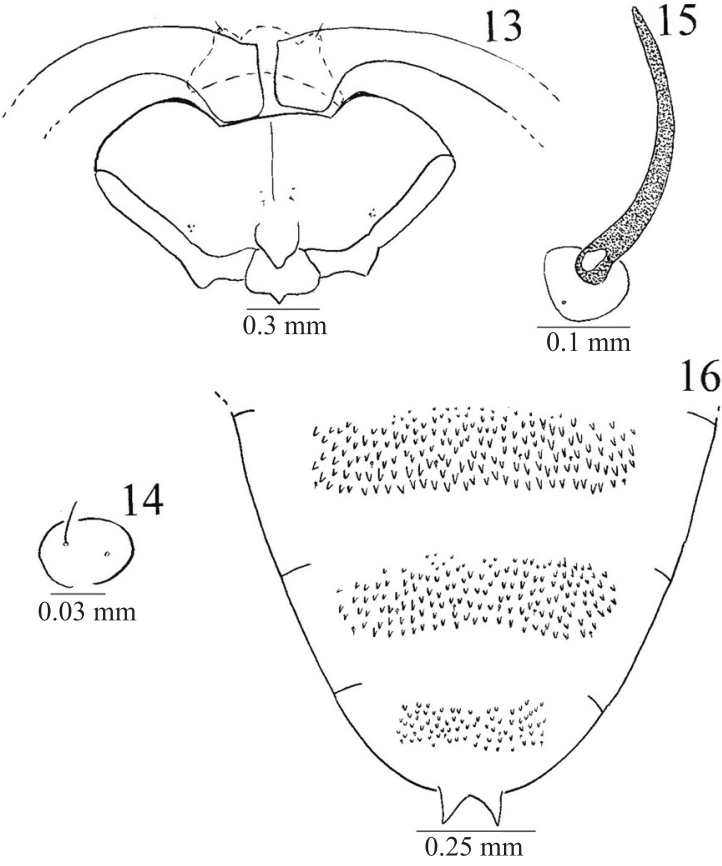

Figs. 13-16. Schizomyia maricaensis sp. nov., pupa: 13, head, frontal; 14 , cephalic setae; 15 , prothoracic spiracle; 16, terminal segments, dorsal.

spur on first tarsomere of each leg. The only other species of this genus with apical spur is S. vitispomum Osten Sacken, 1878, a gall maker on Vitis spp. (Vitaceae) from U.S.A. Besides, the frontoclypeus and anepimeron of the Schizomyia maricaensis show an uncommon great number of setae (more than 40). Others peculiar characters are: male tergite 8 not sclerotized; gonocoxites constricted near midlength; needle part of ovipositor with 1.15-1.4 mm of length; antennal horn absent (pupa) and abdominal segments 3-9 with numerous transverse rows of dorsal spines at discal region (pupa).

This is the first record of Schizomyia on Malpighiaceae.

\section{REFERENCES}

Gagné, R. J. 1994. The gall midges of the Neotropical Region. Ithaca, Cornell University. 352p.

2004. A catalog of the Cecidomyiidae (Diptera) of the World. Memoirs of the Entomological Society of Washington 25:1-408.

MaiA, V. C. 2001. The gall midges (Diptera, Cecidomyiidae) from three restingas of Rio de Janeiro State, Brazil. Revista Brasileira de Zoologia 18(2):583-629.

Maia, V. C. \& Fernandes, G. W. 2005. Insect galls from Serra de São José (Tiradentes, MG, Brazil). Brazilian Journal of Biology 64(3): 1-22. 